\title{
THE USE OF E-LEARNING BASED READING MATERIALS TO IMPROVE THE READING COMPREHENSION OF THE TENTH YEAR MULTIMEDIA STUDENTS OF SMK N 3 SINGARAJA IN THE ACADEMIC YEAR 2012/2013
}

\author{
I Ketut Trika Adi Ana \\ English Education Department, STKIP AH Singaraja \\ adiana_adi@yahoo.co.id
}

\begin{abstract}
ABSTRAK
Membaca adalah salah satu kemampuan yang harus dikuasai oleh pembelajar bahasa asing. Berdasarkan observasi awal yang telah dilaksanakan, siswa kelas $X$ jurusan multimedia SMK N 3 Singaraja memiliki permasalahan dalam memahami bacaan. Hal tersebut dibuktikan dengan ditemuikannya permasalahan yang dialami oleh siswa dalam memahami isi bacaan karena materi membaca yang diberikan oleh guru bahasa Inggris diluar pengetahuan siswa. Oleh karena pentingnya pengetahuan awal dalam aktivitas membaca, materi membaca yang mengacu pada e-learning yang secara khusus telah dikembangkan sesuai dengan kebutuhan dari siswa kelas $X$ jurusan multimedia kemudian digunakan untuk mengajar para siswa. Artikel ini akan menjelaskan hasil dari penelitian tindakan kelas ini, meliputi: (1) peningkatan pemahaman siswa dalam membaca selama penerapan pengembangan materi membaca yang mengacu pada e-learning dan (2) masalah-masalah yang muncul pada pengaplikasiannya.
\end{abstract}

Kata kunci: e-learning, membaca

\section{INTRODUCTION}

Based on the pre-observation that has been conducted on Friday, $16^{\text {th }}$ March 2012, it was found that the tenth year multimedia students of SMK N 3 Singaraja had problems in reading comprehension. It can be seen from the result of the observation during the teaching and learning process and the result of the pre-test that has been administered. From the observation, it was confirmed that the students found difficulties in understanding the text because the topic of the existing reading materials were beyond the students' prior knowledge. Only few students participated in the teaching and learning process. The result of pre-test that was administered to the students during the pre-observation activity confirmed that students had problems in reading comprehension, it can be seen from the students' 
mean score that was only 40.9 (Poor).

Reading skill is a very important skill that should be mastered by the learners of a language. It is because through reading text may provide opportunities for students to study the target language, i.e. the vocabulary, grammar, punctuation, the way to construct sentences, paragraph, and text (Harmer, 2003). Another reason was that the graduates of multimedia are expected to be able to apply the technique in shooting video, digital photography, graphic design, visual communication design, web design, 2D and 3D animation, audio and video editing and visual effect. It means that the daily activities and the targeted jobs of the multimedia students deal with computer programs in which the instructions of the programs are in English. To solve the students' problem in reading comprehension, the researcher taught the students using an e-learning based reading materials which were specially designed based on the multimedia students' need. In other word the topic of the developed elearning based reading materials were about the students' program expertise.

\section{E-Learning}

Some definitions have been formulated by the experts to describe what e-learning or electric learning is. Urdan and Weggen (2000) define e-learning as the use of electronic media, including the internet, intranets, extranets, satellite broadcast, audio/video tape, interactive $\mathrm{TV}$, and $\mathrm{CD}-\mathrm{ROM}$ to deliver the teaching material. They state that e-learning involves a number of applications and processes, including computer-based learning, web-based learning, virtual classrooms, and digital collaboration. The other definition is given by Godio and Terrasse (2003), they state that e-learning refers to the use of electronic device or information to facilitate learning process.

According to Groenendijk and Markus (2010), there are two aspects of e-learning, they are: (1) elearning as computer assisted learning, and (2) e-learning as pedagogy for student-centered and collaborative learning. While, according to Fee (2009), E-learning 
is therefore an approach to traditional learning and development activities that embraces new thinking associated with new technologies, with an emphasis on planning and implementing learning interventions, and managing them - and appreciation of the potential of these technologies informs our understanding of learning in general.

\section{Principle In Teaching Reading}

Harmer (2003) states that there are six principles in teaching reading. Those principles are including:

a. Reading is not a passive skill. Reading means understanding what the words mean, see the picture and the words are painting, and understand the arguments. If readers do not do these things, they only come to the surface of the text that is very easy to be forgotten.

b. Students need to be engaged with what they are reading. If the students are not engaged with the reading text, it will make them uninterested in reading it. Therefore, reading material should be about the topic that they familiar with. c. Students should be encouraged to respond to the content of a reading text, not just to the language. It is important to read the text in order to study the way to use the language, but it is also important to give a chance for the students to give their opinion towards the message that it contains.

d. Prediction is major in reading Book's cover, the headline, the words processed page are the parts of the things that can bring the "hint" for the readers to predict what is the book will be about. In teaching reading, a teacher should be able to build that kind of "hint" in order to make them able to predict what is the text will be about. By doing this, it will help the learners become a better and more engaged readers.

e. Match the task to the topic

In selecting reading material, a teacher should think about the appropriate reading task. It should be in line with the purpose of the reading activity. This is important since the 
inappropriate task will lead the learners to felt bored.

f. Good teacher exploit reading text to the full

Good teacher should integrate reading text into interesting class sequences, using the topic for discussion and further task, using the language for study and later activation.

\section{Reading Comprehension}

Reading comprehension is the ability to construct meaning from a given written text. Reading comprehension is not a static competency; it varies according to the purposes for reading and the text that is involved (Lems, Miller, \& Soro, 2010). In addition, reading can also be defined as a process of saying a written text aloud (oral reading). However, this can be done with or without an understanding of the contents.

Reading comprehension can be classified based on the reader's purposes in reading and the type of reading used (Richard, et.al, 2002). Those classifications are: a. Literal comprehension

Reading in order to understand, remember, or recall the information explicitly contained in a passage.

b. Inferential comprehension Reading in order to find information which is not explicitly stated in a passage, using the reader's experience and intuition, and by inferring.

c. Critical or evaluative comprehension

Reading in order to compare information in a passage with the reader's own knowledge and values.

d. Appreciative comprehension Reading in order to gain an emotional or other kind of valued response from a passage.

\section{RESEARCH METHOD}

This study is a classroom based action research that was conducted in two cycles, in which in each cycle consisted of four steps. Those steps were planning, action, 
observation, and reflection. The subjects of this study were the tenth year multimedia students of SMK N 3 Singaraja in academic year 2012/2013, which consisted of 28 students. Two kinds of data were collected in this study, namely: quantitative data and qualitative data. The quantitative data from the result of pre-test and post-test were used to see the improvement of the students' reading comprehension. Meanwhile, the qualitative data which was collected using the observation sheet was used for finding out the problems in implementing the elearning based reading materials.

The followings are the steps of the classroom based action research that proposed by Kemmis and Mc. Taggart (in Hopkins, 1985):

a. Planning

Planning was the first step in doing this research. During this step the researcher prepared some research instruments that were needed for this research. Those instruments were pre-test, post-test, questionnaire, teaching scenario, lesson plan, material, and observation sheet. b. Action

The second step of this research was the action step. Action was the step when the researcher applies the e-learning based reading material that has been prepared before.

c. Observation

The third step of this research was observation step. In the observation step, the researcher did an observation of the teaching and learning process to find out the result of the application of the e-learning based reading material.

d. Reflection

The fourth step of this research was the reflection step. This was the step when the researcher thought about the next planning, whether the cycle should be continued or not. Moreover, the researcher also had to find out whether or not there are mistakes or problems during the application of the technique during the action process. 
The improvement of the students' reading comprehension during the application of the developed elearning based reading material

\section{a. The Result of Pre-Test}

The pre-test was conducted on Saturday, $17^{\text {th }}$ March 2012. This pretest was conducted to diagnose the students' competency in reading English text. The text that was used to conduct the pre-test entitled "Criteria of Good Photograph". This pre-test covered three cognitive skills, namely to recall specific details, to infer from the text, and to identify main ideas. The pre-test consisted of 20 items of objective test. From those 20 items objective test, 7 items were the questions that required the students to recall the information that available in the text, 8 items were the questions that required the students to find the information that were not explicitly stated in the text or to infer from the text, and 5 items were the questions that asked the students to identify the main idea or the topic sentence of the text. Since each item was scored 5 points, then the maximum score for the pre-test was 100. The students had to finish those 20 items of objective test in 40 minutes. The result of the pre-test can be seen on Table 1 below.

Table 1 The result of Pre-Test

\begin{tabular}{l|l|r|r|r|r|l}
\hline No & Name & RSI & IT & IM & \multicolumn{1}{l}{$\begin{array}{l}\text { Final } \\
\text { Score }\end{array}$} & Category \\
\hline 1. & S1 & 15 & 15 & 5 & 35 & Poor \\
\hline 2. & S2 & 25 & 20 & 10 & 55 & Poor \\
\hline 3. & S3 & 20 & 10 & 10 & 40 & Poor \\
\hline 4. & S4 & 20 & 15 & 5 & 40 & Poor \\
\hline 5. & S5 & 15 & 10 & 10 & 35 & Poor \\
\hline 6. & S6 & 15 & 15 & 5 & 35 & Poor \\
\hline 7. & S7 & 20 & 10 & 10 & 40 & Poor \\
\hline 8. & S8 & 25 & 10 & 5 & 40 & Poor \\
\hline 9. & S9 & 20 & 10 & 10 & 40 & Poor \\
\hline 10. & S10 & 25 & 15 & 10 & 45 & Poor \\
\hline 11. & S11 & 15 & 15 & 5 & 45 & Poor \\
\hline 12. & S12 & 15 & 20 & 15 & 30 & Poor \\
\hline 13. & S13 & 20 & 10 & 10 & 40 & Poor \\
\hline 14. & S14 & 25 & 15 & 5 & 45 & Poor \\
\hline 15. & S15 & 20 & 15 & 5 & 40 & Poor \\
\hline 16. & S16 & 20 & 15 & 5 & 40 & Poor \\
\hline 17. & S17 & 25 & 25 & 5 & 55 & Poor \\
\hline 18. & S18 & 25 & 10 & 5 & 40 & Poor \\
\hline 19. & S19 & & & &
\end{tabular}




\begin{tabular}{l|l|r|r|r|r|l}
\hline 21. & S21 & 20 & 10 & 5 & 35 & Poor \\
\hline 22. & S22 & 30 & 15 & 5 & 50 & Poor \\
\hline 23. & S23 & 20 & 20 & 10 & 50 & Poor \\
\hline 24. & S24 & 25 & 10 & 5 & 40 & Poor \\
\hline 25. & S25 & 15 & 5 & 5 & 25 & Poor \\
\hline 26. & S26 & 20 & 15 & 5 & 40 & Poor \\
\hline 27. & S27 & 20 & 10 & 10 & 40 & Poor \\
\hline 28. & S28 & 15 & 5 & 5 & 25 & Poor \\
\hline \multicolumn{2}{r|}{ Mean Score } & $\mathbf{2 0 . 4}$ & $\mathbf{1 3 . 6}$ & $\mathbf{7 . 0}$ & $\mathbf{4 0 . 9}$ & Poor \\
\hline
\end{tabular}

\section{Note :}

RSI = Recall specific information

IT = Infer from the text

IM = Identify main idea

From the result of the pre-test on table 1, it can be seen that the students had problem in reading comprehension. From the 28 students there was no one who got sufficient score. All of the students (100\%) got poor score. Moreover, the mean score of the class was only 40.9 that can be categorized as poor. It means that all of the students had problem in reading comprehension. Considering the minimum passing grade that the students had to pass for the English subject in SMK N 3 Singaraja that was 75 , there was no one who passed it. Therefore, a treatment using the developed material was conducted in order to help the students to improve their reading comprehension and at the same time to evaluate the product empirically.

\section{b. The Result of Post-Test I}

The post-test I was conducted on Saturday, $12^{\text {th }}$ May 2012. In this post-test, there were 20 items of objective test that should be answered by the students in this test. Those 20 items of objective test consisted of 6 items about recalling specific information that available on the text, 8 items about inferring the information which were not explicitly stated on the text, and the rest 6 items were about identifying main idea or topic sentence. 
Table 2 The Result of Post-Test I

\begin{tabular}{|c|c|c|c|c|c|c|}
\hline No & Name & RSI & IT & IM & $\begin{array}{l}\text { Final } \\
\text { Score }\end{array}$ & Category \\
\hline 1. & S1 & 25 & 0 & 25 & 50 & Poor \\
\hline 2. & S2 & 30 & 20 & 25 & 75 & Good \\
\hline 3. & S3 & 30 & 5 & 30 & 65 & Sufficient \\
\hline 4. & S4 & 30 & 15 & 30 & 75 & Good \\
\hline 5. & S5 & 30 & 0 & 25 & 55 & Poor \\
\hline 6. & S6 & 30 & 10 & 20 & 60 & Sufficient \\
\hline 7. & S7 & 25 & 20 & 30 & 75 & Good \\
\hline 8. & S8 & 30 & 15 & 25 & 70 & Sufficient \\
\hline 9. & S9 & 30 & 0 & 25 & 55 & Poor \\
\hline 10. & $\mathrm{~S} 10$ & 30 & 15 & 30 & 75 & Good \\
\hline 11. & S11 & 30 & 15 & 30 & 75 & Good \\
\hline 12. & S12 & 25 & 0 & 30 & 55 & Poor \\
\hline 13. & $\mathrm{~S} 13$ & 30 & 10 & 30 & 70 & Sufficient \\
\hline 14. & S14 & 30 & 5 & 25 & 60 & Sufficient \\
\hline 15. & S15 & 30 & 15 & 30 & 75 & Good \\
\hline 16. & S16 & 25 & 15 & 30 & 70 & Sufficient \\
\hline 17. & S17 & 30 & 15 & 30 & 75 & Good \\
\hline 18. & S18 & 30 & 20 & 30 & 80 & Good \\
\hline 19. & S19 & 30 & 10 & 25 & 65 & Sufficient \\
\hline 20. & S20 & 30 & 10 & 30 & 70 & Sufficient \\
\hline 21. & S21 & 30 & 0 & 25 & 55 & Poor \\
\hline 22. & S22 & 30 & 10 & 25 & 65 & Sufficient \\
\hline 23. & S23 & 30 & 10 & 30 & 70 & Sufficient \\
\hline 24. & S24 & 30 & 15 & 30 & 75 & Good \\
\hline 25. & $\mathrm{~S} 25$ & 25 & 0 & 30 & 55 & Poor \\
\hline 26. & S26 & 30 & 20 & 30 & 65 & Sufficient \\
\hline 27. & S27 & 30 & 5 & 30 & 60 & Sufficient \\
\hline \multirow[t]{2}{*}{28.} & S28 & 25 & 15 & 30 & 60 & Sufficient \\
\hline & Mean Score & 28.9 & 10.3 & 28.0 & 66.3 & Sufficient \\
\hline
\end{tabular}

RSI = Recall specific information

IT = Infer from the text

IM = Identify main idea

From the result of the post test I on table 2 , it can be seen that the mean score of the students increased from 40.8 (poor) in the pre-test into 66.3 (Sufficient) in the post test I. In other words, the students' mean score was increased 25.5 point. In this post-test I the number of the students who got good score was 9 students $(32.1 \%)$. The number of the students who got sufficient score was
13 students (46.4\%). While, there were 6 students $(21.5 \%)$ who got poor score.

\section{c. The Result of Post-Test II}

The post test II was conducted on Friday, $18^{\text {th }}$ May 2012. The text that was used in this post-test II was "How to Review a Product" there were 20 items of objective test that need to be answered by the students. 
From the 20 questions, 6 of them were about recalling specific information that was explicitly stated in the text, 8 questions were about inferring information from the text, which was implicitly stated on the text, and 6 questions were about identifying main idea or topic sentence.

Table 3 The Result of Post-Test II

\begin{tabular}{|c|c|c|c|c|c|c|}
\hline No & Student & RSI & IT & IM & Final Score & Category \\
\hline 1. & $\mathrm{~S} 1$ & 20 & 20 & 25 & 75 & Good \\
\hline 2. & S2 & 30 & 30 & 25 & 85 & Very Good \\
\hline 3. & S3 & 25 & 25 & 30 & 80 & Good \\
\hline 4. & S4 & 30 & 25 & 25 & 80 & Good \\
\hline 5. & S5 & 25 & 20 & 20 & 75 & Good \\
\hline 6. & S6 & 25 & 35 & 25 & 80 & Good \\
\hline 7. & S7 & 30 & 30 & 25 & 85 & Very Good \\
\hline 8. & S8 & 25 & 30 & 30 & 85 & Very Good \\
\hline 9. & S9 & 30 & 20 & 15 & 75 & Good \\
\hline 10. & S10 & 30 & 25 & 25 & 80 & Good \\
\hline 11. & S11 & 25 & 30 & 25 & 80 & Good \\
\hline 12. & S12 & 25 & 25 & 25 & 75 & Good \\
\hline 13. & $\mathrm{~S} 13$ & 30 & 25 & 25 & 80 & Good \\
\hline 14. & S14 & 30 & 30 & 20 & 80 & Good \\
\hline 15. & S15 & 25 & 25 & 30 & 80 & Good \\
\hline 16. & S16 & 25 & 30 & 20 & 75 & Good \\
\hline 17. & S17 & 30 & 20 & 25 & 75 & Good \\
\hline 18. & $\mathrm{~S} 18$ & 30 & 25 & 30 & 85 & Very Good \\
\hline 19. & S19 & 25 & 30 & 25 & 80 & Good \\
\hline 20. & $\mathrm{~S} 20$ & 25 & 25 & 25 & 75 & Good \\
\hline 21. & $\mathrm{~S} 21$ & 25 & 25 & 25 & 75 & Good \\
\hline 22. & $\mathrm{~S} 22$ & 30 & 30 & 25 & 85 & Very Good \\
\hline 23. & S23 & 30 & 30 & 25 & 85 & Very Good \\
\hline 24. & $\mathrm{~S} 24$ & 25 & 30 & 30 & 80 & Good \\
\hline 25. & $\mathrm{~S} 25$ & 30 & 25 & 20 & 75 & Good \\
\hline 26. & S26 & 30 & 25 & 25 & 80 & Good \\
\hline 27. & S27 & 25 & 35 & 25 & 75 & Good \\
\hline \multirow[t]{2}{*}{28.} & S28 & 25 & 25 & 25 & 75 & Good \\
\hline & Mean Score & 27.1 & 26.8 & 24.8 & 79.1 & Good \\
\hline
\end{tabular}

RSI = Recall specific information

IT $=$ Infer from the text

IM = Identify main idea

The result of the Post Test II as displayed on table 3 , it shows that in general the students' comprehension in reading was increased from the post test I, in which the students' mean score on the post-test I was only 66.9 (sufficient) and it increased into 79.1 (good) in post-test II. In other words the students' mean score was increased 12.1 point. From the 28 students, 8 students (28.6\%) got very good score, while the other 22 students $(78.6 \%)$ got good score. There was no student who got below 
the minimum passing grade. It means that all of the students had passed the minimum passing grade. Therefore, the cycle for the action research was stopped until the second cycle.

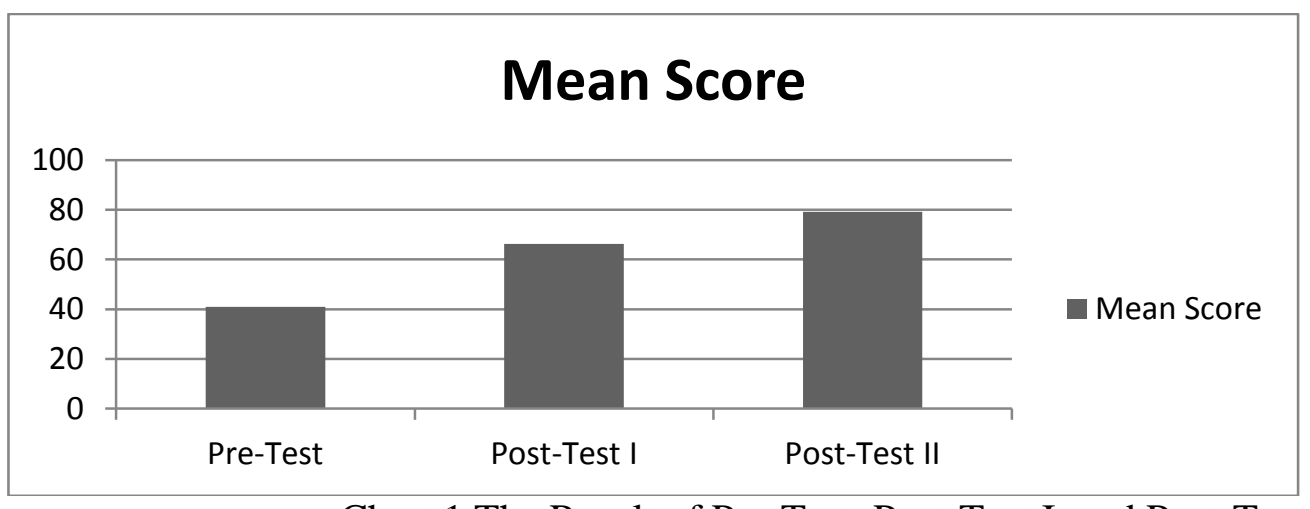

Chart 1 The Result of Pre-Test, Post-Test I, and Post-Test II

The problems during the application of the e-learning based reading materials

Based on the result of the observation during the development process some problems were found, they are:

a. Technical Problem

Developing e-learning based reading material using course management system needs relatively large hosting memory and bandwidth to make it run properly. Since course management system is heavy software, the website that is developed using course management system will be slower if it is compared to the website that is developed by using other software that requires smaller hosting and bandwidth. Course management system needs larger space than content management system because it comes with various functions that cannot be found in those two software, for instance, the ability of course management system in providing interactive quiz, chatting, forum, e-book, automatic scoring system, and automatic score recorder. Therefore, during the application in SMK N 3 Singaraja the elearning website was a bit slower if it is compared to other websites. In addition, the user's password is case sensitive and very complex. It should consist 
of at least 8 characters, in which in those 8 characters there must be at least one upper case, one lower case, numeric, and non numeric character. Since the password was case sensitive, if the user mistype the password he/she cannot log in to the developed e-learning material.

b. Financial problem

Applying an e-learning website in teaching and learning process needs some facilities that include: computers and internet connection. The use of those facilities require more cost if it is compared to the use of the existing handbook. It is obvious since using those facilities means spending some money for electricity, maintenance and internet connection. Considering that reality, it can be said that the implementation of e-learning is costly.

\section{CONCLUSION}

From the result of this study it can be concluded that the application of e-learning based reading material could improve the tenth year multimedia students' reading comprehension. It can be seen from the result of pre-test, post-test I, and post-test II. During the pre-test the students' mean score for reading comprehension test was only 40.9 (Poor). The students' score improved in post-test I of cycle I into 66.3 (Sufficient), and it increased again to 79.1 (Good) in post-test II of Cycle II. However, in implementing the elearning based reading materials, there were two problems found, namely: technical and financial problems.

\section{REFERENCES}

Groenendijk, L. and Markus B. (eds). (2010). Enhancing surveying education through e-learning. Denmark: The International Federation of Surveyors FIG.

Harmer, J. (2003). How to teach english: a introduction to the practice of language teaching. Edinburgh: Pearson Education Limited.

Lems, K. Miller, L.D. \& Soro, T. M. (2010). Teaching reading to english language learners. New York: The Guilford Press.

Richard, J. C., Schmidt, R., Kendriks, W. H., \& Kim, Y. (2002). Longman dictionary of language teaching and applied linguistics $\left(3^{\text {rd }}\right.$ ed). London: Longman Limited. 
I Ketut Trika Adi Ana

Urdan, T. A. and Weggen, C. C.

(2000). Corporate e-learning:

exploring a new frontier. San

Francisco: WR Hambrecht +

Co. 